\title{
The 1753 'Jew Bill’ Controversy: Jewish Restoration to Palestine, Biblical Prophecy, and English National Identity*
}

On 14 July 1753 The Craftsman ran an article purporting to be a news report from one hundred years in the future. The story was considered to be so good that it was almost immediately reprinted in the most popular journal of the day, the London Evening Post. ${ }^{1}$ The piece imagined a dystopian vision in which England had been taken over by Jews. Now renamed 'Judea Nova', the (formerly British) government concerned itself with fighting criminals such as the pork smuggler George Briton, shooting highlanders given to the 'superstition of the Galileans', and banning The Merchant of Venice. ${ }^{2}$ Unsurprisingly, this bizarre synthesis of political satire and anti-Semitic tropes has fascinated writers working on Anglo-Jewish history. ${ }^{3}$ Yet beyond the attack on the Pelham administration and repetition of anti-Jewish hearsay, commentators have missed one of the most interesting aspects of the piece. The report opens with news from Jerusalem concerning the collapse of the middle arch of the temple. The great cost of the repair would be met by the citizens of Great Britain, funded through a lottery for half a million pounds. The presumption in the report, as ridiculous as it might seem, was of Jewish empire with a restored temple, based in Jerusalem. This is driven home by the earlier lead essay in the same issue of the Post. The Jews, the

\footnotetext{
*My thanks to the Journal's anonymous reviewers, editor Martin Conway, and Sasha Handley for their helpful suggestions on an earlier draft of this essay. Earlier versions of this work were presented at a conference on early modern prophecy at Goldsmith's College and at the Nazarene Theological College, and I thank the audiences for their helpful feedback. Early research for this article was made possible by a postdoctoral fellowship funded by the Irish Research Council for Humanities and Social Sciences.

${ }^{1}$ On the role of the London Evening Post in mid-eighteenth-century politics see B. Harris, 'The London Evening Post and Mid-Eighteenth-Century British Politics', ante 110 (1995), pp. 1132-56 and G.A. Cranfield, 'The London Evening Post, 1727-1744', The Historical Journal vi (1963), pp. 20-37.

${ }^{2}$ London Evening Post [Hereafter LEP] 4003, 12-14 July 1753.

${ }^{3}$ For a discussion of both 'News from a Hundred Years Hence' and the 'Jew Bill' see T. M. Endelman, The Jews of Georgian England 1714-1830: Tradition and Change in a Liberal Society (Ann Arbor, MI, 1999), pp. 13-117; T. M. Endelman, The Jews of Britain, 1656-2000 (Berkeley, CA, 2002), pp. 41-77; F. Felsenstein, AntiSemitic Stereotypes: A Paradigm of Otherness in English Popular Culture, 1660-1830 (Baltimore, MD, 1995), pp. 187-214; D. S. Katz, The Jews in the History of England 1485-1850 (Oxford, 1994), pp. 239-283; T. W. Perry, Public Opinion, Propaganda, and Politics in Eighteenth-Century England: A study of the Jewish Naturalization Act of 1753 (Cambridge, MA, 1962); J. Shapiro, Shakespeare and the Jews (New York, NY, 1996), pp. 195-224. For a fascinating recent examination of the influence of the Bill on Richardson's Sir Charles Grandison see B. Latimer's 'Samuel Richardson and the "Jew Bill" of 1753: A New Political Context for Sir Charles Grandison', forthcoming in Review of English Studies.
} 
author reminded his readers, were those who expected 'a temporal messiah and deliverer, under whose victorious banner they are to fight their way to their Jerusalem again'. ${ }^{4}$ The fictitious news report imagined what would happen if they succeeded.

'News from a Hundred Years Hence' and other similar productions were just one part of the controversy that raged over the Jewish Naturalization Act of 1753, commonly (and inaccurately) described as the 'Jew Bill' by contemporaries. ${ }^{5}$ A relatively minor measure, the fact that the Bill caused one of the most sustained political clamours of the $1750 \mathrm{~s}$, and an uncharacteristic burst of open English anti-Semitism, has led to wide scholarly attention. Centring on the question of what it meant to be English, the debates surrounding the Bill illuminate important questions of identity, religious tolerance and anti-Semitism. Yet while work on the Bill has explicated the political, social, and anti-Semitic elements involved in it, the important role prophecy played is largely ignored, despite writers on both sides of the question repeatedly referring to the idea of Jewish restoration to Palestine. This oversight is important for two reasons. First, ignoring the role of prophecy in the debate has led to scholars missing the continuing importance of eschatology in eighteenth-century religious discussion, and thus overlooking the theological issues that the Bill generated for contemporaries. How, asked ministers and pamphlet writers, were the prophecies concerning the Jews to be understood in the context of attempts to naturalise them? Second, a failure to examine prophecy leads to one of the most important influences on English thinking on Judaism being overlooked: the idea of the restoration of the Jews to Palestine. The debate on the 'Jew Bill' was conducted with a background narrative of prophecy, which looked for this restoration as a key prophetic event. Such 'Restorationism' was a common theme in English

\footnotetext{
${ }^{4}$ LEP 4003. 12-14 July1753.

${ }^{5}$ The name has stuck and is used in most of the secondary literature on the subject. The name is distasteful in its derogatory use of 'Jew', as well as misusing the term 'Bill'. A Bill refers to a measure still under discussion and not yet on the statute book. When the Bill was passed into law, it became an Act of Parliament, although contemporaries continued to refer to the 'Jew's/Jew Bill'. I follow them in describing the Act as a Bill here for the sake of consistency.
} 
eschatology from the sixteenth century onwards. ${ }^{6}$ While often seen as connected to the controversies of the Civil War and Protectorate, the idea of Jewish restoration continued to be popular in England through the later seventeenth and early eighteenth century. In Richard Cogley's term, such readings of biblical prophecy can be described as 'Judeo-Centric', as they focused heavily on the key role the Jewish people would play in the end times. In particular, Jewish armies would overturn the Ottoman Empire and liberate the Holy Land, either before or after a mass Jewish conversion to Christianity. Such Restorationist hopes could be driven by contemporary events, such as Sabbatai Sevi's messianic claims in the mid-1660s, or the defeat of the Ottomans at Vienna in 1683, but did not depend upon them. They presumed a highly militarised and politically charged restoration in which the Jews (with God's help) overthrew those who had oppressed them. Indeed, many proponents of Judeo-centric eschatology presumed the eventual supremacy of Jews over Gentiles, as God would restore the full land claims promised to his people in the Old Testament. As the Jews would eventually be honoured above other people groups, many Judeo-centrists believed that nations would be judged on the basis of how well (or badly) they had treated the Jewish people. $^{7}$

These prophecies offered a background that unnerved opponents of the Bill and reminded its supporters that England would be judged on the basis of their relationship to the Jewish nation. The suggestion that England might one day take orders from Jerusalem was not limited to satire, but was a serious consideration on both sides of the debate. This article examines the way in which these prophetic ideas were used in the literature surrounding the

\footnotetext{
${ }^{6}$ R. Cogley, 'The Fall of the Ottoman Empire and the Restoration of Israel in the "Judeo-Centric" Strand of Puritan Millenarianism' Church History lxxii (2003), pp. 304-32; A. Crome, “"The Proper and Naturall Meaning of the Prophets": The Hermeneutic Roots of Judeo-centrism in Puritan Eschatology', Renaissance Studies xxiv (2010), pp. 725-41.

${ }^{7}$ W. Johnston, Revelation Restored: The Apocalypse in Later Seventeenth-Century England (Woodbridge, 2011); N. I. Matar, 'The Controversy over the Restoration of the Jews in English Protestant Thought, 17011753', Durham University Journal 1xxx (1988), pp. 241-56.
} 
Jew Bill, arguing that a better understanding of them will enable a more in-depth and nuanced discussion of Christian views of Jews in eighteenth-century England. These debates on Jews, coloured by prophecy, played an important role in national identity formation for both supporters and opponents of the Bill. This argument is addressed across three sections. The first provides background to the controversy and argues for the centrality of religion in debates on the Bill. The second and third both address the question of the restoration of the Jews and national identity in the political controversy surrounding the Bill - as both opponents and supporters argued that Jewish restoration to Palestine was key for understanding the broader political issues raised by the legislation.

Naturalisation represented more than a change of citizenship. Instead, it recognised the naturalised individual as a native-born subject of the British monarch, and allowed them to enjoy the benefits befitting that status. An un-naturalised immigrant in England faced a number of legal disabilities, including being unable to have an heir or own land, being barred from owning ships (and thus the colonial trade), and paying 'alien duties' on all imports, usually around double the standard tax rate. ${ }^{8}$ For those immigrants who wanted to change their status, two options were open. Denization, granted by the Crown, removed some of the disabilities that lay upon immigrants, but kept the alien duties in place. The second option was full naturalisation, which required (an expensive) private act of parliament. ${ }^{9}$ Jews faced a further problem. According to a statute of 1609 , naturalisation included taking communion in the Church of England. In this context, the sacramental test was seen as a guarantee that the immigrant was serious about claiming a full English identity, including membership of the

\footnotetext{
${ }^{8}$ D. Statt, 'The City of London and the Controversy over Immigration, 1660-1722', The Historical Journal xxxiii (1990), pp. 45-61.

${ }^{9}$ Statt reports that denization cost around $£ 25$, naturalisation around $£ 65$.
} 
national church. It therefore aimed to keep not only Catholics, but also undesirable foreign Protestants out of the country. ${ }^{10}$

For many within the English Jewish community naturalisation was of little or no practical concern. All Jews born within Britain were considered natural born citizens, regardless of their religion. While Jews born in the country were still barred from voting, taking degrees at the universities and serving in government positions, these disabilities were shared by all non-Anglicans. ${ }^{11}$ Yet for those who had been born abroad, or who had entered England as merchants, naturalisation offered obvious financial and legal benefits. The English Jewish community had itself undergone a transformation over the course of the eighteenth century. By the 1750s the Sephardi community in London was noted for its prosperous nature. ${ }^{12}$ While many had made their money through trade, the Sephardi were associated in the popular imagination with brokering, stock-jobbing and the organisation of lotteries, all activities that were commonly seen as being of dubious moral value, despite their value to the government. ${ }^{13}$ In general, rich Sephardim were indistinguishable from other members of the English upper classes - wearing fashionable clothes, owning country mansions and marrying into the higher echelons of English society.

However, by 1753 the Sephardi community had been outstripped numerically by the large numbers of Ashkenazi Jews who had emigrated from Germany and Poland from the

\footnotetext{
${ }^{10}$ Statt, pp. 46-7. It is important to note that supporters of naturalisation were aware that the majority of immigrants from Europe, while Protestant, would not be Anglican. A 1709 Whig act had allowed immigrants to be naturalised cheaply and to confirm their Protestantism by taking the sacrament in any Protestant church. Around 10,000 immigrants, mostly from the Palatinate, took advantage of the measure before a Tory government repealed it in 1711. The Jew Bill must therefore be seen against the background of a longer debate on the economic advantages (or disadvantages) associated with immigration.

${ }^{11}$ A point made by Endelman, Jews of Georgian England, pp. 40-43.

${ }^{12}$ The Lord Mayor and Corporation of London petitioned Charles II to expel the Jews in 1664. In 1673, when indicted for 'riotous assembly' for conducting worship, Charles ordered charges dropped against Jews. A move to charge thirty seven Jewish merchants under recusancy laws in 1685 was again overturned by the crown. See Katz, Jews in the History of England, pp. 107-45 and Endelman, Jews of Georgian England, pp. 17-22.

${ }^{13}$ Endelman, Jews of Britain, pp. 41-77; Perry, Public Opinion, pp. 11-12. Prominent members of the Sephardi congregation, such as Samson Gideon and Joseph Salvador, were important government financiers and, along with other Jewish investors, had helped to prevent a bank run in London during the Jacobite rising of 1745.
} 
early 1700 s onwards. Generally arriving with little or no English, the Ashkenazi immigrants continued to wear traditional dress and generally took up low paying occupations - peddling, collecting old clothes, or engaging in street vending. Financial hardship was commonplace. The challenge of poor relief was a significant strain upon the centre of Ashkenazi religious life, Duke's Place synagogue, while relations with the Sephardi were often marked by snobbery and disdain from their wealthier co-religionists. ${ }^{14}$ For the majority of poor Ashkenazi immigrants, naturalisation was thus of little concern.

In the eyes of the English public distinctions within the Jewish community meant little. Caricatures of a figure such as financier Samson Gideon dressed in fashionable clothing, but speaking in the broken English of a recently arrived Ashkenazi immigrant were commonplace, despite his being born and brought up in England. ${ }^{15}$ When the debates over the Jewish Naturalization Act began, there was seldom much awareness of the fact that the Jewish community was diverse and combined a number of different traditions.

The Naturalization Act should have been uncontroversial. It built upon the 1740 Plantation Act which allowed Jews to be naturalised if they resided for seven years in the American colonies. In January 1753 Joseph Salvador had written to the Duke of Newcastle, one third of the ministry's ruling 'triumvirate', to request that Jews be allowed to apply for private acts of naturalisation by substituting the oaths of supremacy and allegiance for taking the sacrament. ${ }^{16}$ Newcastle's brother Prime Minister Henry Pelham, and Lord Chancellor Hardwicke, the other key members of the Ministry, raised no objections. Lord Halifax introduced a bill to allow for this proposal in the House of Lords on 3 April 1753. It progressed without major difficulties and while debates in the Commons were heated, it

\footnotetext{
${ }^{14}$ Endelman, Jews of Georgian England, pp. 166-91.

${ }^{15}$ See for example 'The Grand Conference or the Jew Predominant' (October 1753) reprinted in Perry, Public Opinion, pp.4-5.

16 The letter, dated 14 January 1753, is found in British Library, Add. MSS 33053. A reprint is available in Samuel, 'The Jews in English Foreign Trade', pp. 367-8.
} 
attracted little outside controversy prior to its second reading in mid-May, having passed its first reading by a margin of 95 to 16 . Opposition to the Bill began to become more widespread around the second reading on 15 May. Prior to its final reading on 22 May, a number of petitions circulated among merchants. One, from Portuguese merchants, claimed that the measure would destroy their trade by angering the Spanish and Portuguese who were notorious for their hatred of Jews. Two petitions in favour of the Bill, of government origin, were also presented to the Commons before the debate. A final petition resulted from a rushed meeting of the Aldermen and Common Council in London, and charged the Bill with devastating economic, political and religious effects. Signed by the Lord Mayor and approved by the Common Council, it was seen as an affront to the dignity of parliament - not only insulting the bishops who had passed the measure in the Lords, but in raising such serious objections to policy so late in the Bill's process. Despite increased opposition in the Commons, the Bill was sent for royal assent on 22 May $1753 .{ }^{17}$

The very limited nature of the measure needs to be emphasised. This was not a proposal for general naturalisation. The individual wishing to be naturalised was still required to obtain a private act of parliament at considerable expense. ${ }^{18}$ Neither was there thoroughgoing Jewish support for the Bill. Gideon, who had predicted the unwelcome attention legislation would bring, resigned his membership at Bevis Marks in protest at the synagogue's implication that he supported the measure. ${ }^{19}$ Nonetheless, both points were lost in the growing clamour that continued throughout the summer of 1753. A concerted campaign against the Bill in the anti-ministerial London Evening Post, a paper which

\footnotetext{
${ }^{17}$ Perry provides a detailed breakdown of the debate over the Bill and the parliamentary reaction. See Perry, Public Opinion, pp. 45-72.

${ }^{18}$ See $\mathrm{n} .9$ above.

${ }^{19}$ The London Evening Post noted at the very start of the controversy that 'Some of the wisest amongst the disciples of Moses disapprove the scheme so warmly pushed by their less prudent brethren, as they perceive it will expose them to much Odium' (LEP 3979, 17-19 May 1753). Thomas Birch told Philip Yorke in September that Gideon's resignation was the "talk of some mirth" in London (Birch to Yorke, 15 Sept. 1753, B[ritish] L[ibrary] Add MS 35398, fo. 158r).
} 
provided much popular material for the regional press, led to widespread publicity of the measure. ${ }^{20}$ Critics imagined the government to be in league with a Jewish lobby (led, ironically, by Gideon) planning to naturalise all Jews resident in Britain and encourage mass Jewish immigration. The continued criticism, combined with an upcoming General Election in 1754, resulted in the Ministry moving to end the controversy. The 'Jew Bill' was never a plank of government policy, and despite the confidence of some that 'no British parliament whatever...will ever cancel so laudable, and advantageous an institution as is the Jew Act'21 it was repealed on 28 November $1753 .^{22}$ No Jews had made use of its provisions.

The question of how to interpret this bizarre episode in Anglo-Jewish history has consistently puzzled historians. Thomas Perry proposed that the debate should be viewed through a political lens as an example of the still strong divisions between Whig and Tory ideology that had been seen, in a Namierite interpretation of the period, to have faded into insignificance by the $1750 \mathrm{~s}$. To a large extent the debate was not about Jews at all, but about using a convenient stick to beat the government with. Claims of religious concern were therefore a mask for political intent. ${ }^{23}$ Yet while the political background was undoubtedly important, to overemphasise it is to risk marginalising the very real religious concerns that did emerge. As critics of Perry have noted, while religion could serve as a front for political attacks, many of the attacks or defences of the Bill based on Christian motives were entirely

\footnotetext{
${ }^{20}$ G.A. Cranfield, 'The London Evening Post and the Jew Bill of 1753', The Historical Journal viii (1965), pp. 16-30.

${ }^{21}$ The Unprejudiced Christian's Apology for the Jews (London, 1753), p. 84

${ }^{22}$ This was the date of the Commons' approval of repeal. The Bill was proposed by Newcastle on 15 November, and passed by the Lords on 22 November. The Commons received the Bill on the 23 November, and it received its third reading on the 28 th. Royal assent was given on 20 December.

${ }^{23}$ Perry, Public Opinion, pp. 161-99. This interpretation has recently been reiterated by D. Feldman (see 'Conceiving Difference: Religion, Race and the Jews in Britain, c.1750-1900', History Workshop Journal 76 (2013), pp. 160-86). There is certainly some truth in this view of things. See the claims that the furore surrounding the act was an election strategy in Josiah Tucker, A Second Letter to a Friend Concerning Naturalizations (London, 1753), p. 3 and The Motives to the Senseless Clamor Against the Act Concerning Jews Exposed, and the Act set in a true light (London, 1753), p. 7. Thomas Birch wrote to Philip Yorke on 23 June 1753 that the clamour "is now evidently design'd to influence the Elections next year" (BL Add MS 35398 fo. $120 \mathrm{v}$ ).
} 
serious. ${ }^{24}$ The number of pamphlets arguing about biblical history should be seen as an important sign of this. An overemphasis on the political aspect of the debate also risks dismissing genuine anti-Semitism in discussions over the Bill as mere rhetoric. ${ }^{25}$ AntiSemitic attitudes were certainly present in England, although these do not appear to have resulted in outbreaks of violence against Jews. ${ }^{26}$ While this should not downplay the seriousness of anti-Semitism in England, it does illustrate that the bellicose rhetoric of the debate was not designed to promote pogroms. As Todd Endelman has noted, even with the Jew Bill controversy, England remained a nation in which Jews were comparatively untroubled compared to their European co-religionists. ${ }^{27}$

While it is vital to recognise the importance of both political concerns and English anti-Semitism in the debate on Jewish naturalisation, the centrality of religion and national identity should also be recognised as key areas in the discussion. My analysis here is a development of the positions recently adopted by James Shapiro, Dana Rabin and Michael Ragussis, all of whom see the debate on the Bill as an attempt to redefine English religious and national identity at a time of crisis. All three writers emphasise the way in which Jewish otherness worked as a marker by which English identity could be formed. Shapiro saw the debate as revolving around the 'Jewish other...trying to claim for itself a part of

\footnotetext{
${ }^{24}$ J. Champion, 'Toleration and Citizenship in Enlightenment England: John Toland and the Naturalization of the Jews, 1714-1753', in O. P. Grell and R. Porter, eds, Toleration in Enlightenment Europe (Cambridge, 2000), pp. 133-56; Endelman, Jews of Georgian England, pp. 24-26; Harris, 'London Evening Post', pp. 1144-48.

${ }^{25}$ Felsenstein, Anti-Semitic Stereotypes, pp. 187-214.

${ }^{26}$ The charges made against the Jews in pamphlets and newspapers were horrendous, including William Romaine's suggestion that Jews had 'a dead, livid aspect' (A Modest Apology for the Citizens and Merchants of London $2^{\text {nd }}$ edition (London, 1753), pp. 8-9) and accounts of crucifying children (e.g. Archaicus, Admonitions from Scripture and History, from Religion and common prudence relating to the Jews (London, 1753); Britannia, An Appeal to the Throne against the Naturalization of the Jewish Nation (London, 1753).) Yet to place a disproportionate emphasis upon these reports presents an unbalanced picture of the debate as a whole. Anti-Semitic feeling in the press does not appear to have broken out into open violence against Jewish communities, although Jews were publicly insulted at Covent Garden and a Jewish peddler murdered in Wales (LEP 4066, Dec 1-4).

${ }^{27}$ Endelman, Jews of Georgian England, pp.272-88; See also Shapiro, Shakespeare, p. 199.
} 
Englishness'. ${ }^{28}$ As the idea of the Jew as a firmly defined other threatened to break down, so writers used the debate to explore their own fears of a national identity that would be undermined by infiltration. Aware of the divisions raised by the still fragile Act of Union, recent Jacobite risings, and the execution of Dr Cameron in June 1753 for his role in Elibank Plot, those opposed to the Bill projected their fears of national instability onto the imagined Jewish threat. ${ }^{29}$ Firm barriers between Jew and Gentile therefore had to be rebuilt, and the anti-Jewish pamphleteers attempted to do this by an extreme 'othering' of the Jewish people that was soon matched in the aftermath of the controversy by the portrayal of 'outlandish' Jews on the stage as a stereotypical paradigm of Jewishness. ${ }^{30}$ While this position is broadly persuasive, it requires nuancing. This can be added by taking the religious, and particularly the prophetic, concerns expressed in the debates more seriously. In doing so, it becomes clear that the centrality of the idea of Jewish and Gentile separation was based firmly upon the Bible, and in particular, on Old Testament prophecies. Opponents of the Bill worried that the government was in danger of undermining England's identity through deliberately attempting to falsify Old Testament prophecy. In their eyes Pelham's administration was part of a wider deist plot to hasten the destruction of the Church of England. Focusing on prophecies thus helped to rebuild the essential difference between Jew and Gentile, and to prove the validity of Christianity. Their fears of Jewish military might were made possible by the continuing rhetoric of Restorationist prophecy which focused upon the power possessed by the Jewish people. The idea of the Jews as a ferocious army, motivated by desperation for land, had distinct prophetic roots and provided a powerful image to draw upon. This discourse, focused

\footnotetext{
${ }^{28}$ Shapiro, Shakespeare, p. 207. He is consciously building on then-recent historiography of Catholic alterity and national identity in L. Colley, Britons: Forging the Nation, 1707-1837 Rev. edition (London and New Haven, CT, 2009); G. Newman, The Rise of English Nationalism: A Cultural History 1720-1830 (New York, NY, 1987).

${ }^{29}$ D. Rabin, 'The Jew Bill of 1753: Masculinity, Virility, and the Nation', Eighteenth-Century Studies xxxix (2000), pp. 157-71.

${ }^{30}$ M. Ragussis, Theatrical Nation: Jews and Other Outlandish Englishmen in Georgian Britain (Philadelphia, PA, 2010), pp. 118-38.
} 
on land and the treatment of 'natives' by a foreign power, also provided an opportunity for writers to reflect concerns and aspirations of empire.

While most work has focused on the rhetoric produced by the opponents of the Bill, when we turn to those writing in favour of the measure, the picture is both complicated and significantly expanded. It is here, and not among the Bill's opponents as Nabil Matar has claimed, that we find a strong and consistent emphasis on the idea of the restoration of the Jews to Palestine. ${ }^{31}$ Just as with the Bill's opponents, for these writers the naturalisation of the Jews served to build up English national identity. Their works emphasise that Englishness had always been fluid and inclusive. However, even when incorporated within the English body politic, the Jews retained an eschatological separation which would see them return to Palestine. It is in providing the conditions that would lead to this return that England could find its role and reconstruct its sense of national identity. In using Restorationism as a lens through which to view the Jew Bill controversy, it becomes possible to see the debate as more than just a passing political storm ${ }^{32}$ and instead view it as part of the continuing discussion of England's role in prophecy that had generated such excitement in the seventeenth century, and would do so again in the $1790 \mathrm{~s} .{ }^{33}$ Debates over the role of prophecy in the Jew Bill controversy were particularly conducive to discussions of national identity as they opened up a series of related questions which touched on these other elements of identity construction. Prophecy raised questions of England's role in the drama of the Apocalypse,

\footnotetext{
${ }^{31}$ Matar, 'Controversy over the Restoration of the Jews', pp. 249-56.

${ }^{32}$ Cranfield describes it as 'a curious interlude in English politics... arousing tremendous passions at the time with no lasting effects whatever'. ('London Evening Post and the Jew Bill', p. 30).

${ }^{33}$ For the continued importance of prophecy in the later seventeenth century see Johnston, Revelation Restored. For the 1790s see C. Garrett, Respectable Folly: Millenarians and the French Revolution in France and England (Baltimore, MD, 1975); S. Juster, Doomsayers: Anglo-American Prophecy in the Age of Revolution (Philadelphia, PA, 2003) and D. Madden, The Paddington Prophet: Richard Brothers's Journey to Jerusalem (Manchester, 2010). This is not to imply that prophecy was always taken seriously, or seen as respectable. The response to the French Prophets who appeared in London in the early eighteenth century demonstrates this (see H. Schwartz, The French Prophets: The History of a Millenarian Group in Eighteenth-Century England (Berkeley, 1980)).
} 
imperial ambition, the issue of national guilt before God, and the link between the Church of England and the nation as a whole. $^{34}$

Historians have largely dismissed the use of prophecy in the debate as rhetorical posturing or as a form of satire. It would be wrong to deny that this was the case with some of the work produced against the Bill - cunning rabbis representing the Ministry or reworkings of Genesis in which Jews drove 'Pelhamites' from the land were clearly not intended to be taken entirely seriously. ${ }^{35}$ The use of such abstracted satire for political purposes, including invented 'prophecies', was an established tool of the press in the mid-eighteenth century. ${ }^{36}$ As Jeremy Black noted, the Ministry was well-aware that some newspaper satires were so ridiculous that they could be safely ignored as having little impact on public opinion. ${ }^{37}$ Yet even bearing this in mind, the Ministry appear to have taken religious attacks on their positions seriously. Josiah Tucker, the economist and clergyman who was commissioned to write an official response to criticism, thus made addressing the question of prophecy and the Jew Bill one of his central concerns: 'one would think from the clamours that have been raised, that the question was, whether the temple at Jerusalem was to be re-established' ${ }^{38}$ As

\footnotetext{
${ }^{34}$ This should not suggest an overly simplistic picture when it comes to national identity formation. As Peter Mandler has argued, national identity is more complex and multivalent than is often recognised in approaches which focus upon its definition in terms of 'the other' (See 'What is "National Identity"? Definitions and Applications in Modern British Historiography', Modern Intellectual History iii (2006), pp. 271-297. While discussions about Jews were used as one way of defining national identity in the eighteenth century, they were certainly not alone in that role, as questions of religious position, relation to Catholicism, understandings of Europe, local identity and class were all elements in forging an individual's sense of nationhood in the period. See, for example: T. Claydon, Europe and the Making of England 1660-1760 (Cambridge, 2007);

T. Claydon and I. McBride, eds, Protestantism and National Identity: Britain and Ireland c.1650-c.1850 (Cambridge, 1998); K. Wilson, The Island Race: Englishness, Empire and Gender in the Eighteenth Century (London, 2003).

${ }^{35}$ LEP 4047 Oct 18-20 1753; LEP 4029 Sept 6-8 1753.

36 J. Black, The English Press 1621-1861 (Stroud, 2001), pp. 30-36.

37 J. Black, The English Press in the Eighteenth Century (London, 1987), pp. 117-118.

38 Josiah Tucker, A Letter to a Friend Concerning Naturalizations (London, 1753), p. 15.
} 
Stephen Taylor noted in his discussion of attempts to set up an Anglican episcopate in America in the mid-eighteenth century, both clergy and the Ministry were fearful of a popular backlash and return to cries of the 'Church in danger' which had marked the Sacheverell controversy in Anne's reign. The government recognised that religious commitment was powerful and viewed it as prudent to avoid controversy in the area. Indeed, Taylor notes that the reaction to the Jew Bill served to confirm that the Ministry had made the right strategic decisions in their policy, as it demonstrated the extent to which religious feelings still ran high. ${ }^{39}$ Indeed, in August 1753 the Archbishop of Canterbury encountered this first hand when, during a visit to Lewes, he found himself facing an angry crowd shouting 'No Jews!'40 The opposition press often painted itself as the defender of religion and printed straightforward devotional material. ${ }^{41}$ This should provide context for the debates of 1753 . Questions of prophecy were raised not only in the press, but in parliament; debates on Jewish restoration emerged in The Gentleman's Magazine and London Magazine as well as in the London Evening Post. Even the satires found some of their success through their ability to draw on background knowledge of Judeo-centric prophecy.

While it would be wrong to claim that Judeo-centrism was the established way of reading biblical prophecy, as eschatology was always a controverted category, it had remained an important element of prophetic hopes after 1660. As Warren Johnston's recent work has shown, the millenarian speculation of the 1650s did not vanish at the Restoration, but was instead employed in more politically conservative forms ${ }^{42}$ The idea of a mass-Jewish conversion was commonly held, and the concept of a restoration to Palestine was something that was reiterated regularly in authors from a variety of traditions. The idea features

\footnotetext{
${ }^{39}$ S. Taylor, 'Whigs, Bishops and America: The Politics of Church Reform in mid-Eighteenth-Century England', The Historical Journal xxxvi (1993), pp. 331-356.

40 Thomas Birch to Philip Yorke, 11 Aug 1753, BL Add MS 35398, fos. 145r-v.

${ }^{41}$ Black, English Press in the Eighteenth Century, pp. 248-257.

42 Johnston, Revelation Restored.
} 
prominently in the works of Isaac Newton and William Whiston, ${ }^{43}$ was affirmed in John Locke's Paraphrase...on ... Romans, ${ }^{44}$ and can be found in Thomas Burnet's posthumously published treatise on Jewish restoration. ${ }^{45}$ A focus on these sorts of prophecies was also a useful corrective to deists. Charles Leslie's 1689 Short and Easie Method with the Jewes, frequently reprinted up until the 1750 s, repeatedly reminded potential Jewish readers of the literal fulfilment of prophecies of their judgement and constant separation from all other nations. Such a fulfilment served as a rejoinder to claims that the prophecies were invented ex eventu, and presumed future fulfilment: 'And [the Jewish nation] may be more glorious than all this that I have said. Even all that temporal grandeur and empire which you expect' ${ }^{46}$ In 1726 William Lowth, prebandry of Winchester and chaplain to its bishop, felt secure enough to claim that Old Testament prophecy should be understood as referring to 'the happy state of the millennium, which may be supposed to begin after the Jews are restored to their country' in a book dedicated to the Archbishop of Canterbury. ${ }^{47}$ In 1730, the Church of Scotland historian Robert Millar's History of the Church contained an appendix designed to convert the Jews. The book, dedicated to George II and attracting several hundred subscribers including the Duke of Buckingham, casually commented that the Ottoman Empire would have to be overthrown prior to Jewish conversion, as: 'having the Land of Israel in his possessions, we may be sure that [the Jews] shall never peaceably enjoy the inheritance of their fathers again, as long as he hath Power to hinder it' ${ }^{48}$ It is noteworthy that Judeocentrism could be held within any of the millenarian positions that dominated eschatological

\footnotetext{
${ }^{43}$ For example: Isaac Newton, Observations upon the Prophecies of Daniel and the Apocalypse of St John (London, 1733); William Whiston, The Literal Accomplishment of Scripture Prophecies (London, 1724). For more on this see A. Shear, 'William Whiston's Judeo-Christianity: Millenarianism and Christian Zionism in Early Enlightenment England' in J. Karp and A. Sutcliffe, eds, Philosemitism in History (Cambridge, 2011), pp. 93-110.

${ }^{44}$ John Locke, A Paraphrase and Notes on the Epistle of St Paul to the Romans (London, 1707), p. 111.

${ }^{45}$ Thomas Burnet Appendix to the Ninth Chapter of the State of the Dead (London, 1729).

${ }^{46}$ Charles Leslie, A Short and Easie Method with the Jews Eighth Edition (London, 1737), p. 136.

${ }^{47}$ William Lowth, A Commentary upon the Prophecy of Daniel and the Twelve Minor Prophets (London, 1726), p. 363 .

${ }^{48}$ Robert Millar, "Discourse to Promote the Conversion of the Jews" in The History of the Church under the Old Testament (Edinburgh, 1730), p. 6.
} 
debates during the early eighteenth century. ${ }^{49}$ Daniel Whitby, who popularised the notion that Christ would return after a Christianised millennium, explicitly argued for Jewish restoration - his point of dispute with premillennialists (who argued that Christ would return to inaugurate a millennial period) being whether or not the Jerusalem temple would be restored. ${ }^{50}$ Meanwhile others, such as the Baptist John Gill in his own Exposition of the Bible (1746-66), were arguing for the importance of Jewish restoration combined with the premillennial return of Christ. $^{51}$

New works in this area had appeared in the years leading up to 1753. Robert Clayton, Bishop of Clogher, published his Dissertation on Prophecy in 1749, in which he concluded that the Jews would be restored concurrent with the destruction of popery and that Jerusalem was promised 'an exaltation higher than all other nations'. ${ }^{52}$ Also published in 1749, David Hartley's Observations on Man sketched out a more controversial scenario. Hartley linked the restoration of the Jews with what he argued would be the inevitable decline and destruction of both civil and ecclesiastical power. 'As the downfal of the Jewish State under Titus was the occasion of the publication of the gospel to us Gentiles,' he suggested, 'so our downfal may contribute to the Restoration of the Jews, and both together bring on the final publication and prevalence of the true Religion'. ${ }^{53}$ Having been published only four years prior to the debate over naturalisation, Hartley's work linked the idea of Jewish restoration with a belief in the inevitable destruction of the political status quo. This is a point worth remembering in discussions of the implications of prophetic fulfilment in 1753.

\footnotetext{
${ }^{49}$ While some writers adopted the premillennial position after mid-seventeenth century commentator Joseph Mede (in which Christ returned prior to the start of the millennium to inaugurate it), others followed Daniel Whitby's influential work in arguing for a postmillennial return of Christ (Christ returns after the conversion of the world).

${ }^{50}$ Daniel Whitby, A Paraphrase and Commentary on the New Testament Vol. II (London, 1718), pp. 147-59 and 'A Treatise of the True Millennium' in Paraphrase, pp. 1-10.

${ }^{51}$ On Gill and premillennialism see C. Gribben, Evangelical Millennialism in the Trans-Atlantic World, 15002000 (Basingstoke, 2011), pp. 51-70.

${ }^{52}$ Robert Clayton, A Dissertation on Prophecy (Dublin, 1749), pp. 72-3.

${ }^{53}$ David Hartley, Observations on Man Vol. II (London, 1749), p. 375. For the downfall of the civic powers see pp. 366-72.
} 
While these works do not suggest that Judeo-centrism was the normative mode of prophetic speculation, the texts nonetheless demonstrate that interest in Jewish restoration remained in the mid-eighteenth century, rather than disappearing in the $1660 \mathrm{~s}$. As ideas of Jewish restoration were current in the period, they provided a backdrop for the use of prophecy in the discussions that followed. While the debates of 1753 represent a flaring up of interest in prophetic matters due to their political currency, it would be wrong to paint this as an isolated moment of interest. Discussions of prophecy were ongoing before, and continued after, the repeal of the act. Editions of The Gentleman's Magazine for January and February 1753, for example, featured letters relating to the question of the likelihood of the Beast of Revelation 16 being identified with China. ${ }^{54}$ Correspondents to The London Magazine in February 1756 debated the possibility of recent earthquakes being linked to the Apocalypse. ${ }^{55}$ As Jeremy Gregory has recently argued, the eighteenth century was as much an 'age of faiths' as an 'age of reason', ${ }^{56}$ and an awareness of the important role that religion continued to play in the period should open us to the possibility that, for some at least, apocalyptic speculation continued to be legitimate. This awareness is a necessary part of taking the 'lived religion' of the eighteenth century seriously. ${ }^{57}$

\footnotetext{
54 The Gentleman's Magazine Jan. 1753, p. 90; Feb. 1753, pp. 116-119.

55 The London Magazine Feb. 1756, pp. 67-8.

${ }^{56}$ J. Gregory, "Transforming the "Age of Reason" into "An Age of Faiths": or, Putting Religions and Beliefs (back) into the Eighteenth Century”, Journal for Eighteenth Century Studies xxxii (2009), pp. 287-305.

${ }^{57}$ See J. Shaw, Miracles in Enlightenment England (New Haven, CT and London, 2006), pp. 1-20; P. Mack, 'The Unbounded Self: Dreaming and Identity in the British Enlightenment' in A. M. Plane and L. Tuttle, eds, Dreams, Dreamers, and Visions: The Early Modern Atlantic World (Philadelphia, PA, 2013), pp. 207-225.
} 
The claim that religious concern among the Bill's opponents was merely political posturing under another name proved offensive to those who saw themselves as standing for the Church of England. 'It is alleged', wrote one frustrated pamphleteer, 'that all this ferment has been excited with no other view, than only with the hopes of misleading the people, and making a party at the next general election; yet I am inclined to think that upon a serious and unprejudiced view of the consequences, which are likely to attend it, they will become of a different opinion'. ${ }^{58}$ This 'different opinion' was systematically laid out by a variety of writers and consisted of three main areas. The first saw that naturalisation would constitute a denial of the prophecies that the Jews were cursed to be a wandering nation for their $\sin$ in crucifying Christ. The second area, which bears an obvious relation to the first, feared that by naturalising the Jews, England would also be claiming a share in God's curses against the Jewish nation. The third area expressed a fear of the Jewish people, who might attempt to claim England as their own country or use it as a launching pad for reclaiming Palestine.

Combined with general attacks on the Jews as dangerous foreigners who practiced an alien faith, the fear that the Pelham administration was attempting to act against God's will was a primary concern. The Jews were 'appointed by GOD to be scattered over the face of the whole earth, 'till they would believe in CHRIST, and take him as their King and Saviour, which they and the Turks will surely do, before the end of time'. ${ }^{59}$ As that time had not yet come, however, the government was putting profit ahead of prophecy by ignoring these clear prohibitions of allowing the Jews to become a gathered nation. 'The arguments from the several prophecies relating to the dispersion of the Jews, to their becoming a by-word and reproach among all nations (which are to this day literally fulfilled)' noted George

\footnotetext{
${ }^{58}$ A Candid and Impartial Examination of the Act Passed Last Session of Parliament for permitting the foreign JEWS to be naturalized (London, 1753), p. 10. See also J.E., Some Considerations, p. 21. 59 J.E., Seasonable Remarks on the Act Lately Pass'd in Favour of the Jews; Containing Divers Weighty Reasons for a Review of the Said Act (London, 1753), p. 14.
} 
Coningesby, 'are all of too great moment to be lightly passed off with an irreligious sneer'. ${ }^{60}$ The measure, stormed another writer, 'must needs be looked upon as an impious endeavour to thwart the divine decree, against [God's] deservedly rejected people: Nay, I know not whether such an attempt to impede God's wrath, may not properly be termed open rebellion against him'. ${ }^{61}$ Samuel Eccles was even more downcast at the prospect. 'But alas! What are we in this nation now about?' he asked his hearers in a sermon in July 1753 . The government had acted in 'express contradiction to God's word, spoken by the mouth of all his holy prophets, to admit these men, still denying, nay blaspheming the name of Christ, citizens of our Jerusalem; to naturalize and incorporate with men who bear witness and allow the deeds of their fathers!' He concluded with a further question for his audience: 'Is Christianity clean gone, and in England is it no more to be found? ${ }^{62}$

The exact prophecies that were apparently being violated by the government were particularly those in Deuteronomy 28, which predicted a series of curses, including exile, for disobedience to God, and Christ's prophecy of Jerusalem's destruction, seen to have ended the Jewish polity for good. These biblical injunctions were mixed with the legend of the wandering Jew, a figure supposed to have cursed Christ on his way to Calvary, and have been condemned to wander the earth without rest ever since. ${ }^{63}$ Theologically, the Jews' continued existence as a separate people could be interpreted in two ways - either as implying a future restoration, or suggesting that they had been kept separate as a witness against their sin. Opponents of the Bill usually favoured the second option. To naturalise them appeared to be breaking down the barrier which had been previously been presumed between Jew and Gentile, imagining that Jews could freely intermingle with the English. The witness of their

\footnotetext{
${ }^{60}$ George Coningesby, The Jewish Naturalization considered, with respect to the voice of the People (London, 1753), p. 21.

${ }^{61}$ A Candid and Impartial Examination . p. 11.

${ }^{62}$ Samuel Eccles, The Candid Determination of the Jews in Preferring a Thief and a Robber before our saviour: A Sermon preached June 10, 1753 (London, 1753), p. 14.

${ }^{63}$ Felsenstein. Anti-Semitic Stereotypes, pp. 55-89.
} 
punishment would thus be lost. 'May we not reasonably conclude from what we see', asked one opponent, 'that it is the will of providence, they should be preserved as a distinct people, never to be incorporated with other nations, whilst they continue in the same faith?' ${ }^{64}$ To naturalise the Jews was to help confirm them in their unbelief, a point picked up by several authors, not least in the popular press. 'By the Christian Revelation the Jews were to be a dispers'd and scatter' $d$ people. They by theirs expect a Restoration: We are going by this Bill to collect them together, and thereby, as far as in us lies, to falsify our own Prophets and verify the predictions of theirs' grumbled Britannicus in the London Evening Post. ${ }^{65}$ Arthur Murphy's interlude The Temple of Laverna, originally written in 1752 and republished the following year, imagined that Jews would view the granting of naturalisation as proof that Christianity was not divinely revealed. 'Shall we have a fixed place of residence at last!' exclaimed a broker, 'Have we baffled the prophecies of the Galileans?' ${ }^{66}$ One ballad writer thus wondered how the process of naturalisation could fit into God's plan: 'Are these then the people that mark'd with the brands/ That the $\mathrm{C}-\mathrm{G}-\mathrm{Y}$ have preach'd shall inherit no land/ Which now they gain'd against God's command'. ${ }^{67}$ These fears were not limited to the press. Indeed, they had been raised in the original parliamentary debates on the Bill. Sir Edward Isham noted that by the Bill: 'we are giving lie to all the prophecies in the New Testament, and endeavouring, as far as we can, to invalidate one of the strongest proofs of the Christian religion'. ${ }^{68}$ One writer to The Gentleman's Magazine was so concerned that Jewish prophecy was undermining Christian belief that he suggested a project for removing 'Jewish' phrases from the Psalms: 'that while we are opposing the favour that seems intended for them, we

\footnotetext{
${ }^{64}$ [Jonas Hanway], A Review of the Proposed Naturalization of the Jews (London, 1753), p. 28.

${ }^{65}$ LEP 3980, 19-21 May 1753.

${ }^{66}$ Andrew Murphy, 'The Temple of Laverna' in A Collection of the Best Pieces in Prose and Verse Against the Naturalization of the Jews (London, 1753), p. 19.

67 'The Jews Triumph, a Ballad' in The Tom-Tit, or, Something to Please Everybody (London, 1753), p. 4.

${ }^{68}$ The Parliamentary History of England, From the Earliest Period to the Year 1803 (London, 1813), xiv: 1381. This speech was reprinted in the June 1753 edition of The London Magazine, pp. 265-266.
} 
may not be praying for their establishment and prosperity in the very words which they themselves use' ${ }^{69}$

These concerns about the validity of the prophecies, as Nabil Matar has noted, were often linked with the fear that deists were seeking to undermine the rational basis of Christian faith by deliberately attempting to prove the prophecies false. ${ }^{70}$ If Jews could be naturalised, feared some of the Bill's opponents, then the curses against the Jews in the Old Testament would have been shown to be inaccurate, and the Bible would have been revealed to be of dubious reliability. By naturalisation, argued one of the London Evening Post's letter writers, 'we labour, as much as in us lies, to defeat the prophecies in the New Testament, which is destroying the very essentials of our religion, and may subject us to the wrath of God' ${ }^{71}$ 'Judaism and Deism lift up high their proud and unbelieving heads, whilst humble Christianity lies under a cloud' bemoaned Britannicus in early August. ${ }^{72}$ The ballad 'The Jews' Triumph' made the link explicit: “'But 'tis hop'd that a mark will be set upon those/ Who were friends to the Jews, and Christians' foes/ That the nation may see how Deism grows' ${ }^{73}$ Significantly, this was the stanza used to advertise the work in the London Evening Post. ${ }^{74}$ According to one correspondent, the Jew Bill was thus a good way of revealing its supporters as dangerous to the Church: 'Believers will take care to mark them out as Freethinkers, Latitudinarians, and Deists' ${ }^{75}$ Another writer to the paper felt that such attempts to violate the prophecies were doomed to fail: 'The wretches who are trying to falsify the prophecies, are, in truth, fulfilling them; for the Jews are every day becoming more

\footnotetext{
${ }^{69}$ The Gentleman's Magazine. Sept 1753, pp. 428-29.

${ }^{70}$ Matar, 'Controversy over the Restoration of the Jews', p. 241.

${ }^{71}$ LEP 4012, 2-4 Aug. 1753.

${ }^{72}$ LEP 4013, 4-6 Aug. 1753.

73 'The Jews Triumph', p. 4.

${ }^{74}$ LEP 3991, 14-16 June 1753.

${ }^{75}$ LEP 4071, 13-15 Dec. 1753.
} 
and more an execration, and would think none but such as are wilfully blind could help seeing it'. ${ }^{76}$

Writers with these concerns had a ready model for those who deliberately tried to disprove prophecy: Roman Emperor Julian the 'apostate', who in 365 CE had tried to rebuild the Jerusalem temple and reinstitute ceremonial worship in direct contradiction of the New Testament. As Julian's temple had supposedly been destroyed by fire from heaven and an earthquake, his project served as an ominous warning to those who denied prophecy. A petition from the Sheriff and Aldermen of Wiltshire to their parliamentary representatives in August thus asked 'May we not with reason, apprehend that we shall draw upon ourselves the resentment of almighty God for our endeavours to establish the body politic of the Jews in the same manner as Julian the Apostate?'77 The government 'imitate the impiety of the Apostate Julian, by endeavouring, like him, to falsify the Word of God'. ${ }^{78}$ Supporters of the Bill were baffled by the comparison. 'Let me ask any serious sober person', one author wrote, 'is there the least similitude between the legislature's passing this bill in favour of the Jews, and Julian's declaration...in open defiance of Christ, in order to prove him to have been a false prophet and an imposter?'79 For political reasons, it was certainly useful to paint Pelham as a second Julian, working as part of a deist conspiracy to undermine the Church of England. Yet there is no reason to think that some of the concern at least was not genuine, connecting as it did with High Church suspicion of Whig 'enthusiasm' and links to deism. ${ }^{80}$

Yet concerns did not end with the fear that prophecy was being attacked. Rather, it was the threats contained within the prophecies and the worry that England could inherit

\footnotetext{
${ }^{76}$ LEP 4027, 1-4 Sept. 1753.

${ }^{77}$ LEP 4014, 7-9 Aug. 1753; See also Collection of the Best Pieces, p. 80 and a petition from the electors of Chichester against the Bill (LEP 4043, 9-11 Oct 1753).

${ }^{78}$ LEP 4008, 24-26 July 1753.

${ }^{79}$ A True State of the Case Concerning the Good or Evil which the Bill for the Naturalization of the Jews May Bring upon Great Britain (London, 1753), p. 11.

${ }^{80}$ A concern that Harris notes is symptomatic of the London Evening Post. See Harris, 'London Evening Post', pp. 1153-56.
} 
Jewish guilt for crucifying Christ that emerged as a predominant theme. In many ways this was a reversal of the logic that had been so prevalent in the Whitehall Conference a hundred years earlier, in which it was hoped that England would acquire blessing from her interactions with the Jews. ${ }^{81}$ As with many aspects of the anti-/philo-Semitic binary and national identity formation, it allowed writers to form an external measure by which they could gauge whether the nation was living up to her 'chosen' role. Whereas Judeo-centrists accepted Jews as eternally blessed, and saw Anglo-Jewish relations in that light, their opponents used the same logic to argue that the people were forever cursed. The question for those who supported the Bill was clear: 'Can any Christian state receive such a nation as this into its bosom now, without subjecting itself and all its dependents, to the wrath and curses which God has so solemnly denounced against them, and which has for so many ages pursued and accompanied them in all places?'.82 Again, this concern was present in the Commons debates on the issue. 'There is a curse attends the nation in general' argued Sir John Barnard, 'and I wish, that by bringing them here, we may not bring along with them the curse that pursued them through all countries, and for so many ages' ${ }^{83}$ 'All fellowship and inter-community of Christians with Jews, in rights civil and religious (which cannot but be often intermix'd among people naturaliz'd together)', noted Archaicus, 'must make those partakers in sin and guilt with these, and involve them in their judgement and plague'. ${ }^{84}$ By 'associating or uniting with sinners... must they be undoubtedly pronounced partakers of the same who incorporate and associate with them' argued Eccles, ${ }^{85}$ while Coningesby feared 'a monstrous connection' that would make England 'involved in their guilt'. ${ }^{86}$ 'Would it be of any public benefit to import the wealth of the whole Indies, if there should come a curse

\footnotetext{
${ }^{81}$ See A. Crome, 'English National Identity and the Readmission of the Jews, 1650-1656', Journal of Ecclesiastical History lxvi (2015), pp. 280-301.

82 Britannia, Appeal to the Throne, p. 14.

${ }^{83}$ Parliamentary History xiv: 1395.

${ }^{84}$ Archaicus, Admonitions, p. 21.

${ }^{85}$ Samuel Eccles, Religion the Truest Loyalty, Protestantism no Fanaticism or Judaism (London, 1753$)$, p.18.

${ }^{86}$ Coningesby, Jewish Naturalization, p. 5.
} 
along with it?' asked William Romaine. 'And if there be a God', he concluded ominously, 'a curse there will come with the Jews money'. ${ }^{87}$ The London Evening Post published letters expressing this fear with tedious regularity. Correspondents asked rhetorically whether '[they who] think of being united in a Civil Community with the Jews, have not great reason to be afraid that they shall be united with them in all their plagues and curses?';88 'May we not expect to be involved in the same curse which God has inflicted on them, and be a reproach to all nations forever?'; 89 'May we not, by such an unnatural union, reasonably expect to be incorporated into their curses, and that it will call down upon this nation the just vengeance of the almighty? ${ }^{90}$

Many writers went so far as to describe the nature of the curses that would fall upon England as a result of the naturalisation of the Jews. While their predictions often seemed to veer towards the absurd, when read in the context of Judeo-centric eschatology the visions of England's nightmare fate begin to become much more coherent. It is important to note, as Jane Shaw has argued, that the wondrous continued to hold a fascination in mid-eighteenth century England. Her work on Mary Toft, famous for supposedly giving birth to rabbits in 1716 , shows the persistence of the story into the 1750 s, including her being cited by William Whiston as a sign of the forthcoming restoration of Jews in a 1750 lecture. In 1753 the story of Elizabeth Canning, who had supposedly survived for a month on a single jug of water and half a loaf of bread after being kidnapped by gypsies, had captivated newspaper and magazine readers as a possible supernatural wonder. ${ }^{91}$ Of course, as E.J. Clery has pointed out, the popularity of these sorts of cases might be representative of a shift towards viewing

\footnotetext{
${ }^{87}$ [William Romaine], An Answer to a Pamphlet, entitled, Considerations on the Bill to Permit Persons Professing the Jewish Religion to be naturalized (London, 1753), p. 56.

${ }^{88}$ LEP 3986, June 2-5 1753. Both Eccles and Romaine were accused of being anonymous writers for the $L E P$. See Harris, 'London Evening Post', pp. 1136-38.

${ }^{89}$ LEP 3991, 14-16 June 1753.

${ }^{90}$ LEP 4024, 30 Aug. - 1 Sept. 1753.

${ }^{91}$ J. Shaw, 'Mary Toft, Religion and National Memory in Eighteenth-Century England', Journal for EighteenthCentury Studies xxxii (2009), pp. 321-338.
} 
the supernatural merely as a titillating spectacle; an experience broadly analogous with attending the theatre. ${ }^{92}$ Certainly, many of the examples mentioned above attracted interest due to their entertainment value. But this was not the case for all of those who followed them. As Shaw argues, press warnings against credulity in such cases suggest that many took them seriously. ${ }^{93}$ Thus while reports of supernatural judgements that would fall on England as a result of naturalising the Jews might seem beyond the realms of possibility, in a context in which wondrous events could be accepted they became at least broadly plausible.

In reversing the usual Restorationist position on the blessings offered to the nation by interactions with the Jews, so the Bill's opponents used the underlying Restorationist narrative of Jewish militarism, connection to Palestine, and messianic expectation to argue against the Naturalization Act. At times they therefore employed satirical re-imaginings of Jewish restoration in their work. 'The ten tribes, when they hear of this Act, will undoubtedly discover themselves and take advantage of it', noted one cynical commentator. ${ }^{94}$ Another believed that 'all Bishops, Priests and persons in Holy orders [will] say and maintain, that the Call of the Jews is now come, and that the Kingdom of Christ is at hand' ${ }^{95}$ One wit in the press suggested that 'an army may be speedily raised for the retaking Jerusalem, which happy event would enable our good friends and new countrymen Israelites to rebuild their temple'. ${ }^{96}$ Of course, for such satire to have its intended effect these writers relied on their readers picking up on the common Restorationist tropes they mocked. The writer of Esther's Suit to King Ahasuerus was obviously familiar with the eschatological position when he

\footnotetext{
92 E.J. Clery, The Rise of Supernatural Fiction, 1762-1800 (Cambridge, 1995), pp. 1-32. In particular, see her examination of the Cock Lane ghost of 1762, a phenomenon which drew spectators include Samuel Johnson and the Duke of York to the site of the supposed haunting.

${ }^{93}$ Shaw, 'Mary Toft'.

94 J.E., Seasonable Remarks, p. 12.

${ }^{95}$ A Proposal humbly offered to the legislature of this Kingdom for the re-establishment of Christianity (London, 1753), p.12.

${ }^{96}$ Collection of the Best Pieces, p. 57.
} 
suggested that 'this seems to prepare the way for the call of the Jews, which the learned say, must preceed the second coming of the Messiah ... and if at the coming of the messiah, London should be fixed on by him, for his glorious reign on earth as his metropolis, will not all nations by that means be subject to Britain, and will not the law go forth from Sion?'97 Another writer imagined that the Act would lead to a land swap: 'Thus the Kingdom of Old Jerusalem will be ours in Reversion, for this giving them Britain in present possession; and there can be no other obstacle to our having the whole land of Canaan for our inheritance, but the opposition of its present possessors'. Even further: 'All the old prophecies will be thus fulfilled; a New Jerusalem, rising like a phenix [sic] out of the ashes of the Old, shall be establish'd in the West, while the Old One in the East will become our Colony, and while both the one and the other shall cry aloud, This is the P-rl----ts doing and it is marvellous in our eyes! 98

For all of this ribaldry, some writers displayed a subtle grasp of Judeo-centric narratives of restoration that was able to aim directly at the roots of concerns over national identity. Perhaps the most remarkable piece in this vein was 'The Prophecy of Shylock', printed by the London Evening Post in late August. ${ }^{99}$ A parody of biblical prophecies of restoration, it is notable for its attacks being entirely focused upon the English rather than the Jews. It is worth quoting at length:

For it shall come to pass, that as I plucked you [the Jews] out, I will return and have compassion on you, and will bring you again, every man to his heritage, and every man to his land. I have heard your complaints with pity, and visited the afflictions of my chosen people, to bring you together again, and establish you for $[\mathrm{sic}]$ an

\footnotetext{
${ }^{97}$ Esther's Suit to King Ahasuerus (London, 1753), p. 16.

${ }^{98}$ LEP 4008, 24-26 July 1753.

${ }^{99}$ For more on Shylock in the controversy see E. H. Anderson, 'Celebrity Shylock', PMLA cxxvi (2011), pp. 935-49.
} 
everlasting kingdom...The land you are now to possess is fruitful and pleasant, and its inhabitants are ripe for destruction... They deck themselves with jewels, [are] wanton in the midst of their wealth: Their young men delight in gaming and drunkenness, and their women play the whore in the open streets... They were honour'd by their neighbours for their wisdom, and princes stood in awe of them for their strength. I fenced them with the walls of the depth; even by the walls of the mighty ocean... I made the mighty bow to their pavilions and covered the ocean with their fleets: Their fame went from one end of the earth to the other... I was their sure rock of defence while they walk'd in my ways; but they forsook the paths of their fathers...Therefore, thus saith the Lord: I will destroy them in my anger. ${ }^{100}$

The passage is surprisingly rich for the concerns it raises relative to national identity. Not only had England betrayed its religious roots, but questions of separation from Europe ('fenced with the walls of the depth'), imperialism, and shifting gender roles also emerge clearly in the imagined biblical narrative. These concerns combined with a much darker fear of Jewish militarism and projects to reconquer the Holy Land. Restorationism had promoted an image of the Jews as superior to other nations and blessed with military power, neither of which attributes appeared to recommend Jewish readmission. 'The notion they suck with their milk is, that they are a great nation and all mankind usurpers of their sovereignty', noted J.E, 'this consideration reconciles their pertinacious adherence to the religion of their forefathers; and invalidates their claim to mix with any other nation'. ${ }^{101}$ The Jews, noted another, 'shortly also expect (we see) their Messias to come and restore them to the country of their ancestors; and being aliens, they would little love the country, and so do little for it' ${ }^{102}$ Indeed, the same author worried: 'if an artful Rabbi should spirit his nation up with the

\footnotetext{
${ }^{100}$ LEP 4022, 25-28 Aug. 1753.

101 J.E., Some Considerations, p. 84.

${ }^{102}$ An Appeal to the Throne, p. 31.
} 
expectation of a future restoration of the Jewish kingdom, as history informs us has often been done, who would be able to defend the crown itself from a people, that have in all times and place, where the least success has buoy'd 'em up, left examples of this imperious and rebellious spirit?' ${ }^{\prime 03}$ The fear that the Jews might raise a Messiah was stated repeatedly. 'As they always blindly expected a temporal messiah and deliverer, under whose victorious banner they are to fight their way to their Jerusalem again, and to flourish there in great splendour and glory', noted 'Christianus', 'so there have never been wanting artful, ambitious, or presumptuous men among them, who from time to time tak[e] advantage of their blind expectation'. ${ }^{104}$ Romaine cited both current prophetic hope amongst Jews and false messiahs from Bar-Kochba to Sabbatai Sevi to prove his point. Repeating the spurious claim that Jews had studied Cromwell's genealogy to see if he could be the messiah, Romaine suggested that Samson Gideon represented a likely candidate at present. ${ }^{105}$ The London Evening Post thought Henry Pelham more plausible. ${ }^{106}$

The unease over messianism combined with the supposed military power of the Jews, might also be seen to offer an arena in which England's own imperial concerns and insecurities might be examined. Opponents of the Bill therefore repeatedly referred to a fear of the loss of land, and the reduction of Britain to the status of a colony. The Duke of Bedford, speaking in the Lords in November, argued that should the Act remain on the statute book 'they might then call this island their own land, and whatever respect some of the superstitious among them might retain for their prophecies, every sensible man would think

\footnotetext{
${ }^{103}$ An Appeal to the Throne, p. 22.

${ }^{104}$ LEP 4003, 12-14 July 1753.

105 [Romaine], An Answer, pp.31-34. Hardwicke, in a letter of October 20 1753, criticised Romaine for this suggestion, describing him as guilty of 'impudence, buffoonery, virulence and insincerity'. While the legend was false, Menasseh ben Israel had suggested Cromwell as a possible candidate for messianic identity in an interview with Arise Evans (see Evans, A Light for the Jews (London, 1664)).

${ }^{106}$ LEP 4029, 6-8 Sept. 1753. See also the anecdote recorded in the previous issue: 'Friend Nathan, said an honest Gentleman at Garraway, can it be true, that your sagacious Nation should be one and twenty times cheated by false Messiahs? Can you doubt it, replied the testy Hebrew, when in spite of all this Experience, you see us, at this day, the Dupe of the twenty-second?' (LEP 4028, 4-6 Sept. 1753).
} 
that had made a happy exchange. ${ }^{, 07}$ Archaicus feared that a corrupt ministry might use Jews as an alternative standing army. ${ }^{108}$ The Gazetteer reported a dream in which the natural inhabitants of a land mercifully allowed 'google-eyed creatures with long whiskers' into their nation, before seeing their government, economy and lands taken over. The natives were eventually expelled 'and the new inhabitants, amid their festivity, proclaimed aloud, 'Now is our Kingdom come' ${ }^{109}$ Similar fantasies were present in 'News from a hundred years hence' and other popular pieces. A poem in the London Evening Post in September 1753 featured a conversation between two Jews, who imagined that Britons would be driven 'into the Sea, as their Christ did the hogs... Then hey for the Land, the blest Land of Canaan!'. ${ }^{110}$ A detailed parody of Genesis 34 found the Jews offering money to the 'Pelhamites' in return for circumcision, only for them to slay 'every Male of the Britons' whilst 'their private parts were sore'. The Jews here conspired together to claim power: 'Shall not their lands, their cattle, their substance, and every beast of theirs be ours?'111 Thomas Birch's distaste at the short-lived Protestor was linked explicitly to its suggestion (based on the Jews' slaughter of their enemies in the Book of Esther) that 'it is not unreasonable for us to fear, That if ever This Land becomes a Land of Goshen to them, it will also become a Land of Bondage to us'. ${ }^{112}$ The London Evening Post attempted to support such claims with more sober reporting. Correspondents reminded readers of the atrocities perpetrated against the Romans and Cypriots by Jews in antiquity, ${ }^{113}$ while Matthew Hale's Primitive Origination of Mankind was quoted to prove that 'if all the Jews...were collected into one body, they would exceed in number any one of the greatest nations in the world, and yield an irresistible army' ${ }^{114}$ Crime

\footnotetext{
107 Parliamentary History xv: 105.

108 Archaicus, Admonitions, p. 28.

${ }^{109}$ Best Pieces, pp. 15-16.

${ }^{110}$ LEP 4032, 13-15 Sept. 1753.

${ }^{111}$ LEP 4047, 18-20 Oct. 1753.

112 The Protestor 3, June 16 1753. For Birch's report see Thomas Birch to Philip Yorke, 16 June 1753, BL Add MS 35398 fos. $118 \mathrm{r}-\mathrm{v}$.

${ }^{113}$ LEP 4050, 25-27 Oct. 1753; 4054, 3-6 Nov. 1753.

${ }^{114}$ LEP 4056, 8-10 Nov. 1753.
} 
reports shortly after the repeal continued to present the Jews as menacing military figures. The London Evening Post for 5-8 January 1754, for example, featured a story on a continental community threatened by a Lutheran trader 'imagin' $d$ to be either a Jew or a Papist', the description of a Polish converso beheaded for returning to Judaism, and a report of the construction of a Jewish ghetto in Vienna. ${ }^{115}$ As late as May 1754, a report from Bristol described the robbery of a woman by a Jew who cried 'You B---h, you thought to have turn'd us out of Bristol, but now we will do for you all!'116

These images of Jewish violence are striking, particularly as Felsenstein has argued that the idea of the feeble Jew was a common one until the rise of Daniel Mendoza and other Jewish pugilists in the early nineteenth century. ${ }^{117}$ Rather, as Rabin recognised, the image of Jews presented throughout the pamphlets was: 'threatening and aggressive'. ${ }^{118}$ In finding a source for these images, Rabin is right to suggest a fear over the breakdown of gender roles. But combined with the other uses of Restorationist prophecy in the debate, including its subtle reworking by those who opposed the Bill, it is suggestive both of the continued strength and importance of the Judeo-centric narrative in forming impressions of Jews into the mid eighteenth-century, and broader concerns over empire. The idea of the Jews as an unstoppable military force was a powerful one, and a useful image which could be drawn upon by the press. Certainly in the context of David Hartley's 1749 Observations, in which he combined Jewish restoration with the destruction of the civil and ecclesiastical settlement, the idea of a Jewish return to Palestine could be seen as inherently threatening. Such an image also revealed insecurities about Britain's imperial role, which resurfaced in the wake of the consistently reiterated fear of being reduced to a French colony which echoed from the

\footnotetext{
${ }^{115}$ LEP 4081, 5-8 Jan. 1754.

${ }^{116}$ LEP 4132, 9-11 May 1754.

${ }^{117}$ Felsenstein, Anti-Semitic Stereotypes, pp. 228-32.

${ }^{118}$ Rabin, 'Jew Bill', p. 160.
} 
1745 Jacobite rising until the end of the Seven Years War. ${ }^{119}$ The narrative of Jewish military and trade based colonialism warned of the Bill's opponents thus suggested the precarious nature of Britain's ability to maintain her hold over land (both at home and overseas), as well as revealing a latent acknowledgement of the violence inherent in the colonising process. It is therefore significant that the image of the Jews as violent enslavers fixated on profit, tallied with the popular critique of Creole planters in the period recently traced by Jack P. Greene. ${ }^{120}$ Thus the Gazetteer's dream narrative highlighted the peaceful trading nature of the Jews whose obsession with material gain led them to reduce the native inhabitants of the land which had welcomed them to abject poverty, while the Post linked growing colonial influence to corruption: 'As they increase in Number, so will they increase in power; and as they increase in power, so will they increase in cruelty; 'till be Degrees, we find ourselves become the Slaves of merciless and cruel Tyrants' ${ }^{121}$ The allusion to British imperial endeavours in 'Shylock's' boast that 'our brave Men of War shall scower the main/ And our Red-coats restore Judah's Sceptre again'122 was obvious. It is therefore significant that the methods Jews were accused of using to fulfil the prophecies anticipated criticism of the East India Company that would emerge in the 1760s. Both the Gazetteer dream and the Genesis 34 parody included a pattern of feigned friendship to natives, followed by increasing numbers of colonists and tyranny until the natives were reduced to slavery or expelled. This can be compared with Samuel Foote's 1768 play The Nabob, which recounted that the Company were 'admitted as friends' had 'a beneficial commerce with the inoffensive and innocent people' until 'at length we growing too strong for the natives, we turn them out of their lands,

\footnotetext{
119 J. P. Greene, Evaluating Empire and Confronting Colonialism in Eighteenth-Century Britain (Cambridge, 2013), pp. 36-43; K. Wilson, The Sense of the People: Politics, Culture and Imperialism in England, 1715-1786 (Cambridge, 1995), pp. 137-205; P.J. Marshall, 'A Nation Defined by Empire, 1755-1776' reprinted as Chapter VI in 'A Free though Conquering People: Eighteenth-Century Britain and its Empire (Aldershot, 2003).

${ }^{120}$ Greene, Evaluating Empire, pp. 20-49.

${ }^{121}$ LEP 4063, 24-27 Nov. 1753.

${ }^{122}$ LEP 4032, 13-15 Sept. 1754.
} 
and take possession of their money and jewels'. ${ }^{123}$ All of this suggests that reflections on prophecy helped to contribute to the wider debates on imperialism current in mid-eighteenthcentury England. The presumption in Judeo-centrism of a flourishing Jewish empire invited comparison and critique to Britain's own endeavours. While the Bill's opponents denied that there could ever be any connection of Jewishness with Britishness, the Jews ironically became mirrors of Britain's imperial anxieties. ${ }^{124}$

Yet this use of prophecy was flexible. While Matar has argued that those who opposed the Bill did so because it made Jewish restoration to Palestine more unlikely, ${ }^{125}$ in fact for the Bill's opponents the idea of Jewish restoration was a threat to their conception of both Christianity and England. When they spoke about prophecies, almost invariably they meant prophecies of Jewish separation. The one notable exception to this was the Commons debate on the Bill of 15 May 1753. Isham's speech noted that the Jews must be 'without fixed habitation, until they acknowledge Christ to be the messiah, and then they are to be gathered together from all corners of the earth, and to be restored to their native land'. ${ }^{126}$ Barnard, similarly, argued that they would be homeless until 'they have acknowledged Christ to be the messiah: and when they do this, they are to be restored to their native land' ${ }^{127}$ While, at the start of the debate, the prophecies of Jewish restoration were used against the Bill, this quickly faded into the background. Instead, where restoration to Palestine did enter the discussion after this point it was found not among the Bill's opponents, but its supporters.

\footnotetext{
${ }^{123}$ Quoted in Greene, Evaluating Empire, p. 132.

${ }^{124}$ On the idea of natives as 'mirrors' of Englishness see Wilson, The Island Race, pp. 54-91.

125 Matar, 'Controversy over the Restoration of the Jews', pp. 251-53.

${ }^{126}$ Parliamentary History xiv: 1381.

${ }^{127}$ Parliamentary History xiv: 1389.
} 
Much of the Judeo-centric discourse which emerged in the debates surrounding the Bill was aimed at countering the prophetic interpretation that was being offered by its opponents. As discussed above, this tended to focus on the curses God had threatened the Jews with, and the idea that these precluded any form of Jewish incorporation into a Gentile nation. Against this, Restorationist writers aimed to prove that not only was naturalisation possible, but that it was a necessary prelude to the full restoration of the Jews. This position required the standard idea of the Jews as an 'other' used to forge national identity to undergo some modification. These writers simultaneously argued for separation and incorporation - Jews could become English, in that they could share in the benefits of being considered both British citizens and gaining English moral values. However, at the same time they would still be eschatologically separate as they awaited their future restoration to Palestine.

The opponents of the Bill thus mistook the nature of prophecies when they argued against naturalisation. 'This is not the fact', argued Philo-Patriae, 'Christ's prediction was, that their temple should be destroyed and they dispersed, this is verified; but he never said they should not be received as subjects by any nation'. ${ }^{128}$ Edward Weston, writing in the aftermath of the controversy, reminded readers that 'the punishment of the Jews, as a people, consists in their separation from the land of promise, in the destruction of their city, temple and civil government, as exercised in Judaea, whilst God permitted them to continue a nation under his own theocratical superintendency'. ${ }^{129}$ 'Tho' the scriptures inform us, that the Jews shall be dispers'd over the face of the whole earth', stormed preacher Peter Peckard, 'they no

\footnotetext{
${ }^{128}$ Philo-Patriae, Further Considerations on the Act to permit persons professing the Jewish religion to be naturalized by Parliament (London, 1753), p. 62. Edgar Samuel believed Philo-Patriae to be a pseudonym for Joseph Salvador, although I am not convinced (see Samuel, 'The Jews in English Foreign Trade', pp.351-4.). While Philo-Patriae was aware of Jewish customs and Talmudic learning, this was not unusual in the period (see D. B. Ruderman, Judaism and the Search for Christian Identity in Eighteenth-Century England (Philadelphia, PA, 2007)). Neither is the fact that the London Evening Post claimed that Philo-Patriae was Jewish - a common insult against anybody writing in favour of the Bill (see in particularly the Post's treatment of the Sephardi community's [Christian) lawyer, Philip Carteret Webb 'the Jew', 'the Jew lawyer' etc. - e.g. LEP 3997, 4004, 4014, 4122).

129 [Edward Weston], $\triangle I A \Sigma \Pi O P A:$ Some Reflections upon the questions relating to the Naturalization of the Jews (London, 1754), p. 17.
} 
where say, that they shall continue in that condition for ever, but plainly assert the contrary' ${ }^{130}$ Josiah Tucker's official response noted that the prophecies did not exclude the Jews from any nation, and that to claim so showed a severe want of Christian charity. While 'at present under a dreadful delusion, [they] are still the natural branches, and when the divine providence shall think proper, will be grafted in againe, i.e. naturalized'. ${ }^{131}$ As Tucker intimated, to claim that the Jews had been rejected completely was to ignore clear prophecies of their future blessing. As The Gentleman's Magazine concluded in frustration in June 1753, the claim that prophecy was being frustrated by the Bill's opponents 'will for ever stigmatize the present age of moral philosophy, in which every one boasts to detect the frauds of superstition'. This was not, however, because the prophecies were not true, but because they were being interpreted illogically: 'if the prophecies concerning the Jews are not fulfilled, Christianity is not true; and if Christianity is true, these prophecies cannot but be fulfilled' ${ }^{132}$ The Bill's opponents, its supporters argued, were guilty of overlooking God's continued interest in the Jewish people in a way that denied them any relevance other than as markers of judgement. While this was one way in which their continual separation and survival as a people group could be read, it was also possible to recognise that they were kept distinct for a special prophetic purpose. 'What is become of the ancient Babylonians, Egyptians, Greeks, Romans' asked 'A True Believer' rhetorically, 'Do any of them survive in their successors?'133 'If you act consistently with the gospel, and your own doctrine of the call, you ought to protect the Jews, and prevent their ruin', noted the author of Looking Glass for the Jews, 'For if they are to be destroyed, how can the call take place? How can the kingdom of Israel be restored to them?'134 Those who opposed the Bill should thus remember that 'the

\footnotetext{
${ }^{130}$ Peter Peckard, The Popular Clamour Against the Jews Indefensible: A Sermon preached at Huntingdon, October the $28^{\text {th }} 1753$ (Cambridge, 1753), pp. 17-18.

131 Tucker, Letter to a Friend, p. 14.

132 Gentleman's Magazine, June 1753, p. 280.

133 'A True Believer', An Apology for the Naturalization of the Jews (London, 1753), p. 3.

${ }^{134}$ A Looking Glass for the Jews (London, 1753), vii.
} 
Almighty seems still to have a regard to the gracious promises he made to their pious ancestors, that he will not cast them off for ever, but in his own due time, will again distinguish them by his favours'. ${ }^{135}$

What was the future purpose? 'We can have no doubt, but all the prophesies concerning that people will have their accomplishment, in God's good time; as those concerning their dispersion, have been most evidently and remarkably completed', noted one correspondent in the Norwich Mercury. Thus 'we cannot but look with pleasure and delight at any step; which may seem to tend, how remotely so-ever, to their restitution to their own land; whether before or after their conversion to Christianity'. ${ }^{136}$ 'To bring them back from the four winds, to the land of their Fathers,' noted Weston, 'to convert and put them again in possession of Jerusalem, and the holy mountain: This is the true end of the dispersion; the revocation of the decree of their national punishment, the completion of every prophecy'. ${ }^{137}$ The logic of restoration helped the proponents of the Bill, as it combatted claims that the Jews were seeking to take over the country. Somewhat ironically, this meant that while the Jews could enjoy the benefits of naturalisation, this would serve as a prelude for their eventual departure from Britain. In the meantime, it would benefit the nation to bless them. Thus, as Philo-Patriae noted, the Jews 'have no thought of having an independent state in any country, but the Holy Land. What possibly can ever make them desire to leave our obedience, while we let them enjoy their private liberties?'. ${ }^{138}$ 'And let not any of my countrymen be terrified with dreams of a Jewish State and Sanhedrin in our Island as the consequence of their conversion', another pamphleteer advised, 'see with your own eyes, and believe your Bibles. Thus saith the Lord, "Behold, I will take the children of Israel from among the

\footnotetext{
135 An Apology for the Naturalization, p. 4.

${ }^{136}$ Some Queries Relative to the Jews (London, 1753), p. 10. This work reprinted a series of letters from the Norwich Mercury.

137 [Weston], $\triangle I A \Sigma \Pi O P A$, p. 20.

${ }_{138}$ Philo-Patriae, Considerations on the Bill to Permit Persons Professing the Jewish religion to be Naturalized by Parliament (London, 1753), p. 18.
} 
heathen whither they be gone, and will gather them on every side, and bring them into their own land". ${ }^{139}$ For others, those who opposed the Bill were being selective in their use of prophecy. It was common to hear the Jews cursed on the basis of the Old Testament, complained another correspondent to the Norwich Mercury, 'yet although the same God hath said they shall be restored [the Bill's opponents] will not hear of their restoration with patience'. ${ }^{140}$ The debate over the Bill also offered an opportunity for a general discussion of Restorationist ideas. The author of An Explanation of Some Prophecies offered the furore over the measure as a justification for publishing his eschatological speculation, for: 'At a time when the Jews are become the subject of much conversation and much controversy in this Kingdom, it cannot be improper to enquire, as strictly as we can, after the very time of their conversion and restoration to the promised land'. ${ }^{141}$ This restoration was, claimed Weston, the centrepiece of the Bible:

In truth, Sir, the connection of that people with the holy promised land, which was given for a possession to Abraham and his seed for ever, has something in it to my apprehension very extraordinary and remarkable. It is a connection, the importance and value of which may be traced through all the books from Genesis to the Revelations; a connection magnified by the prophets, and adored by the people; regretted most bitterly when broken, and triumphed in when restored. It is the subject of God's almighty's [sic] favour, and of his anger, of his rewards, and of his punishments. It extends from the time of Abraham to that of Titus; and when once more renewed, as renewed it must be, may perhaps out-live the present system. ${ }^{142}$

\footnotetext{
${ }^{139}$ The Crisis, or an Alarm to Britannia's true Protestant Sons (London, 1753), p. 23.

140 Some Queries, p. 28.

${ }^{141}$ An Explanation of Some Prophecies Contained in the Book of Daniel, wherein the particular times of the destruction of the Mahometans and of the Restoration of the Jews are pointed out (London, 1753), p. 13.

142 [Weston], $\triangle I A \Sigma \Pi O P A$, p. 19.
} 
For these writers, the Bill was seen as a first step towards the coming restoration to the land. Even Pelham, in seeking to address concerns that the Bill served to undermine prophecy in May, hinted as much. The Jews could never expect to be 'established in a country which they could call their own' until 'they have acknowledged Christ to be the messiah, and have embraced his religion. If the indulgence proposed to them in this country could contribute to this desirable end, as I think it will, I hope every gentleman will admit that it is a strong argument in favour of the Bill' ${ }^{143}$ This position was stated much more forcefully by those pamphleteers writing in favour of the measure. 'I have observed indeed and sincerely hope it will be so', noted a writer who identified himself only as a member of the Church of England, 'that the conversion of the Jews may be the consequence of this bill... the opinion of their conversion and restoration had been a settled and determined one, strengthened and supported in many passages of scripture'. ${ }^{144}$ 'It is not here said, that the CONVERSION of the JEWS was the thing intended by this ACT', noted the preacher Thomas Winstanley, 'though it would be hard to say it was not. But whatever was the end proposed, or whatever were the motives to it, whether good or bad; if it should hereafter be productive of such good and excellent fruits, we Christians surely shall have no just cause of complaint'. ${ }^{145}$ The Jews might remember 'there are several passages in the same scriptures, which speak of their restoration, as well as their conversion, in the plainest and most expressive terms'; could the Bill, he wondered, be seen 'as something more than human, as something providential, in their favour'? ${ }^{146}$ For some, to fight against the Bill was 'to deny what the scripture so expressly affirms, that they will be restored to the privilege of being the peculiar people of God'. Thus 'the first step towards their restoration will be that God will

\footnotetext{
${ }^{143}$ Parliamentary History xiv: 1415.

${ }^{144}$ An Earnest and Serious Address to The Electors and Freeholders of Great Britain (London, 1753), pp. 1617.

${ }^{145}$ Thomas Winstanley, A Sermon Preached at the Parish-Church of St. George, Hanover-Square, Sunday October 28, 1753: On Occasion of the Clamours against the Act for Naturalizing the Jews (London, 1753), p. 14. 146 Winstanley, Sermon, p. 18.
} 
give them favour in the sight of all sincere Christians'. ${ }^{147}$ This was a somewhat optimistic claim for the Bill's effect given the general tone of the debate.

All of these writers therefore placed the Bill within an eschatological context. It was to act as the catalyst for the conversion of the Jews and the restoration to their land. The implication was that England would have a distinct role to play in Jewish restoration. Just as the Bill's opponents had used prophecy to address imperial anxieties, so its supporters linked the legislation to securing a special destiny for the nation. Some took this literally, with the idea that England would physically restore the Jews occasionally being mooted. The ships of Tarshish mentioned in Isaiah 60, thought one author, 'clearly implies that the first return of these Jews shall be by ships passing along the Mediterranean, from remote islands'. ${ }^{148}$ The privileges that naturalised Jews could now enjoy were therefore prophetic: 'the first setting out of the Jews to their own land will be from England, not only by assistance of an English fleet, but that, by the late naturalization of the Jews here, they may be enabled not only to extend their trade, enrich themselves, but purchase ships of their own'. ${ }^{149}$ However, the predominant eschatological idea linked English piety with the prophetic potential for conversion. Englishness here became a fluid and polyglot identity marker. On one level, this meant that for those in favour of the Bill the Jew was no longer a stable 'other' against which identity could be defined. On another, however, these same writers continued to emphasise the inevitability of Jewish restoration to Palestine. The Jews would thus contribute to English identity, and gain from it those attributes which would prepare them to resume their rightful role as God's people on earth. Thus where their opponents feared pollution of the national body through contact with foreigners, so the Bill's supporters embraced a model in which

\footnotetext{
147 A True State, pp. 31-32.

${ }^{148}$ The Full and Final Restoration of the Jews and Israelites, evidently set forth to be nigh at hand: with their happy settlement in their own land (London, 1753), p. 14

149 Full and Final Restoration, p. 15.
} 
national (and imperial) expansion was deemed to be beneficial. Englishness became the crucible for a truly elect identity.

This idea of elect identity saw the Jews as a blank slate: 'Like cloth ready to receive any dye' as Philo-Patriae put it. ${ }^{150}$ While they may have a separate eschatological identity, this allowed the Jews to incorporate into the nation without any difficulty. This historical process of national integration had been on-going since prehistory. 'But do we remember, that our ancestors, and Christianity itself, were both originally of a foreign growth?', noted the author of Crisis, 'Neither the soil nor the climate produced either. Into what a chaos would this whimsical notion of a native of Great-Britain reduce us! At this rate neither laity nor clergy would find it easy to trace out an hereditary right to their land in religion'. ${ }^{151} \mathrm{By}$ recognising that the nation itself was a mixture of people groups, it was possible to imagine a Jewish presence without difficulty. The claim by some opponents of the Bill that even a Jew born in England should not be considered English was therefore ludicrous: 'Who are the English, than by any other method, than by being born here in England? For is not our nation a mixture of Saxons, Danes, Germans, and French, with the Antient Britons?" ${ }^{152}$ Englishness was therefore not to be defined simply by drawing on the idea of a pure English bloodline, but rather upon ideas of birth right and connection to the inherent qualities of the land. This was certainly partially conditioned by awareness of the compound nature of British identity after the Act of Union. ${ }^{153}$ There was also an awareness of the potential for positive transformations through residence in England, a view which can be seen to tally with the idea that a shared conception of 'Britishness' could be spread to diverse peoples in new territories

\footnotetext{
${ }^{150}$ Philo-Patriae, Further Considerations, p. 7.

${ }^{151}$ The Crisis, or an Alarm, p. 11.

${ }^{152}$ An Address to the Friends of Great-Britain Occasion'd by the Debates among the People and the Answer to Considerations on the Bill for Naturalizing the Jews (London, 1753), p. 7.

${ }^{153}$ Colley, Britons, pp.11-18; J.C.D Clark, 'Protestantism, Nationalism and National Identity, 1660-1832', Historical Journal xliii (2000), pp. 249-76; Colin Kidd, British Identities before Nationalism: Ethnicity and Nationhood in the Atlantic World, 1600-1800 (Cambridge, 1999), pp. 99-122.
} 
in America. ${ }^{154}$ Yet while this model of national identity might have promoted the transformative impact of an outward looking nation, it was resolutely focused on the metropole. This was therefore not a complete repudiation of alterity as a way of defining nation identity. Philo-Patriae illustrated this when he concluded that Jews 'from Spain have the pride, ostentation and jealousy peculiar to that nation... those from Holland and Germany many of the vices of those nations; and, among those of this country, may be found many of the English virtues, and more particularly love of liberty and their country'. ${ }^{155}$

By bringing the Jews into England, the nation would therefore play the key role in converting them in preparation for their return to Palestine. 'The general conversion of the Jewish nation must begin somewhere, and none can tell how soon, why should we endeavour to prevent its beginning here?' asked Tucker. ${ }^{156}$ A Looking Glass for the Jews also posed the same question: 'Unless you can see into future events, and are acquainted with the precise time of their call, how do you know but their naturalization here is the first step to their conversion; and that England is this happy country where this great revolution in the affairs of the world is to commence?'157 'They will not continue long with us', predicted the author of Full and Final Restoration confidently, 'and that even the passing this Naturalization Act, may in some measure, strengthen them both earlier and easier to depart to their own land'. ${ }^{158}$ Thus where the opponents of the Bill worried about the consequences of blessing a people cursed by God, for the supporters of the Bill the opposite was true: 'Let us seriously consider what danger attends the misusing them,' warned Philo-Patriae, 'and I defy any one to shew a nation, either ancient or modern, that has not proved the truth of this menace. The Spanish

\footnotetext{
${ }^{154}$ See P.J. Marshall, 'Britain and the World in the Eighteenth Century: IV, The Turning Outwards of Britain', reprinted as Chapter XVI in 'A Free though Conquering People'.

${ }^{155}$ Philo-Patriae, Further Considerations, p. 7. See also p. 42: 'I ever was of the opinion, that men's geniuses, nationally considered, are equal; where there is any difference, it must arise either from education or circumstances'.

156 Tucker, Second Letter, p. 42.

${ }^{157}$ A Looking Glass, vii.

${ }^{158}$ Full and Final, p. 2.
} 
and Portuguese monarchies have been late instances of it in the strongest manner'. ${ }^{159}$ Weston sombrely noted that the English 'beware, that we curse not those whom God hath not cursed; more especially, as we know not how near that time may be, when it shall please God to fulfil in the eyes of all nations, what remains to be fulfilled of his covenant with their illustrious ancestor [i.e. Abraham]'. ${ }^{160}$

The debate over the Jew Bill was complex and the controversies that surrounded it included a variety of concerns. These included criticisms of the Pelham ministry, worries about the unity of the state, concerns over British imperial projects, and fears over the future of religion. Within all of these categories, Restorationism had a role to play, whether in providing the narrative background that allowed wide discussion of theories of Jewish militarism and takeover, or in continuing to argue for the centrality of the restoration of the Jews and England's role within it. Understanding the importance of continuing Restorationist thought in these debates is important for a number of reasons. For scholars of Anglo-Jewry it helps to explain why Jews were portrayed as violent and land-grabbing by opponents of the Bill. Tapping into a reservoir of Judeo-centric images, they were able to bring the militarised image of the Jews desperate to gain their own land to the foreground and to use it to their political advantage, while addressing contemporary political and imperial concerns.

The use of the Restoration motif also highlights the continuing importance of religion to mid-eighteenth-century political debates. While work on the Jew Bill has often argued that religion was being used primarily for political ends, or merely returning to old anti-Semitic

\footnotetext{
159 Philo-Patriae, Further Considerations, p. 90.

160 Weston, $\triangle I A \Sigma \Pi O P A$, pp. 40-41.
} 
tropes, the way in which Restorationism was used on both sides of the debate highlights the importance of religion for both the Bill's supporters and its detractors. It also helps to explain why the use of religious categories to make either political or anti-Semitic arguments was so effective. Finally, it enables scholars of English identity to further understand the way in which Judaism was used to help construct varied concepts of Englishness in the mideighteenth century. The fact that England's fate was seen as being bound up with the nation's treatment of the Jewish people, and the importance of this in the key debate on what constituted Englishness in mid-century, shows the continued strength of Judeo-centrism as a tool of identity construction. Even when writers emphasised the polyglot nature of their own identity, theoretically dismantling the otherness of the Jews, the idea of restoration and Jewish promotion above the Gentiles, and the belief that God judged nations by the manner in which they treated the Jews, continued to emphasise Jewish difference. Historians of religion in the eighteenth century, particularly those dealing with the interactions between English Christians and Jews, should therefore be alive to the continuing influence of eschatology, and its pervasive influence upon key political debates of the time. 